\title{
Digital Learning Resources and Ubiquitous Technologies in Education
}

\author{
Technology, Knowledge and Learning (Springer)
}

\author{
Mark Anthony Camilleri* \\ Department of Corporate Communication, University of Malta \\ Adriana Caterina Camilleri** \\ Department of Psychology, University of Bath
}

\begin{abstract}
This research explores the educators' attitudes and perceptions about their utilization of digital learning technologies. The methodology integrates measures from 'the pace of technological innovativeness' and the 'technology acceptance model' to understand the rationale for further ICT investment in compulsory education. A quantitative study was carried out amongst two hundred forty-one educators in Malta. It has investigated the costs and benefits of using digital learning resources in schools from the educator's perspective. Principal component analysis has indicated that the educators were committed to using digital technologies. In addition, a stepwise regression analysis has shown that the younger teachers were increasingly engaging in digital learning resources. Following this study's empirical findings educational stakeholders are better informed about how innovative technologies can support our students. In conclusion, this paper puts forward key implications and recommendations for regulatory authorities and policy makers for better curricula and educational outcomes.
\end{abstract}

Keywords: Digital learning resources, ICT in Education, Educational Technologies, Technology Acceptance Model, Principal Component Analysis, Stepwise Regression Analysis.

*Resident Academic Lecturer, Department of Corporate Communication, University of Malta, MALTA Email: mark.a.camilleri@um.edu.mt Tel. +3562340 3742 | Tutor and Researcher, Business School, University of Edinburgh, United Kingdom. 


\section{Introduction}

Digital technologies are permeated in our routine activities; whether we are at school, at work and during our personal engagements. Innovative technologies may have brought powerful, transformative tools which are improving on our quality of lives (Fullan, 2013; Fullan \& Smith, 1999; Prensky, 2001, 2005). Policymakers have quickly recognised the significance of certain technologies as a vehicle for socioeconomic progress. Stakeholders in education are also promoting innovative pedagogical practices by using technology (Fullan, 2013). In a knowledge construction setting, technology becomes a tool to help students access information, communicate information and collaborate with others (Warren, Dondlinger \& Barab, 2008), Fullan \& Smith, 1999). In a similar vein, Kozma (2003:13) reported that; “...when teachers use technology to plan and prepare instruction and collaborate with outside actors, and when students also use technology to conduct research projects, analyse data, solve problems, design products and assess their own work, students are more likely to develop new ICT, problem solving, information management, collaboration and communication skills".

Notwithstanding, access to technologies and electronic resources has increased dramatically in these last few decades. Technologies in education have quickly become part of our everyday life (Prensky, 2001, 2005). The use of ICT is underpinning our students' education (Fullan, 2013). Students from a tender age are acquiring 'digital skills' and expertise in media and information communication technologies (ICT). Many pupils already operate offline specialised software as well as online programmes on internet (Castaño-Muñoz, Duart \& Sancho-Vinuesa, 2014; Tyner, 2014). As a matter of fact, ICT has improved the ways of accessing knowledge, researching, communicating, socialising and succeeding in all levels of education (Hoskins \& Crick, 2010; Smith, Higgins, Wall \& Miller, 2005). Nowadays, many children and teenagers can easily access a personal computer either at home or at school. Many of them are also using their own wireless devices, including smart phones and tablets for many purposes. This contribution suggests that student-centred approaches demand that educators meet their pupils' expectations (McLoughlin \& Lee, 2010; Harkema \& Schout, 2008). It posits that educators ought to respond to 
these new realities as they need to adapt their teaching designs and methodologies to students' abilities, interests and learning styles.

Bocconi, Kampylis \& Punie (2013) suggested that the students' use of digital learning resources during lessons is related to the teachers' confidence level in their digital competences. Inevitably, students are affected by the teachers' stance on ICT in education. The pupils' motivation for digital learning resources may also be correlated to the access and availability of these innovative resources in school environments (Sardone \& Devlin-Scherer, 2010). Wastiau, Blamire, Kearney, Quittre, Van de Gaer \& Monseur (2013) have indicated that students have the highest frequency of digital learning resources when they are taught by teachers who possess appropriate digital skills, who use the internet, including social media in a responsible manner (Hoskins \& Crick, 2010). Moreover, EU (2013) has underlined the importance of high access to ICT infrastructure at school; this recent survey reported that between $20-25 \%$ of European students are taught by digitally competent teachers who have high access to ICT. Academic evidence also shows that increasing professional development opportunities for teachers is an efficient way of boosting ICT use in teaching and learning, since it helps build highly confident and supportive teachers (Smith et al., 2005). In the main, this particular European survey has indicated that the teachers' opinions about the impact of using ICT for learning purposes are very positive and encouraging. As a matter of fact, about $80 \%$ of students are in schools where the school heads also share such beliefs (EU, 2013).

Therefore, it may be wise for European countries to ensure that ICT training is consistently being offered as a compulsory component in all initial teacher education programmes. Arguably, having high access and positive attitudes among educators in schools and colleges does not guarantee the successful engagement of technologies in education. The use of digital learning resources requires ongoing support - not only technical but also pedagogical (Fullan, 2013; EU, 2013). Kozma (2005) advocated that ongoing training and continuous professional development ought to be provided by school staff and others to teachers of all disciplines, including subject-specific training on learning applications. Confident and supportive teachers are highly required to effectively use ICT infrastructure and to exploit its potential. The skillful teachers are capable of making the best use of poor ICT learning environments (Burns, 2013). In this light, this paper explores the educators' attitudes toward 
technology in education. It unfolds their motivations behind their use of digital learning technologies (Sardone \& Devlin-Scherer, 2010; Warren et al., 2008).

\section{Aims and Objectives}

The goals of this project have been reached through a combination of research activities: Firstly, it involved the exploration and analysis of practitioner-oriented tools including national policies and reports as well as international regulatory guidelines, in this regard. The literature review comprises theoretical underpinnings, conceptual frameworks and empirical findings that revolve around the digital learning resources paradigm. This paper deliberates on some of the unresolved issues pertaining to the integration of technology, pedagogy, and change knowledge in the realms of education (Fullan, 2013). Therefore, it considers previous tried and tested measures, namely; 'the pace of technological innovativeness' (De Smet, Bourgonjon, De Wever, Schellens \& Valcke, 2012; Grewal, Mehta \& Kardes, 2004); 'technology acceptance' (Jackson, Mun \& Park, 2013; Cheon, Lee, Crooks \& Song, 2012; Huang, Huang, Huang \& Lin, 2012; Davis, 1989); and 'technology anxiety' (Celik \& Yesilyurt, 2013; Tondeur, van Braak, Sang, Voogt, Fisser \& Ottenbreit-Leftwich, 2012); Meuter, Bitner, Ostrom \& Brown, 2005) for the data gathering process. The empirical study investigates the educators' attitudes for (or against) digital learning resources.

This research was principally guided by the following research question: How do factors such as 'technology acceptance' (Davis, 1989); 'pace of technological innovativeness' (Grewal et al., 2004) and 'technology anxiety' (Meuter et al., 2005) affect educators' attitudes towards the use of digital learning resources? The quantitative study is based on the formulation of three hypotheses which were derived from relevant literature. It is the intention of this project to advance theory on the subject of technologies in education and to put forward an empirical study in the field of 'digital learning resources' in the Maltese educational setting. This study sheds light about the real motivations and constraints for the use of digital learning resources (Sardone \& Devlin-Scherer, 2010). The constructed variables have unfolded the educators' attitudes and perceptions about the costs and benefits of ICT in education. Hence, regression analysis investigated the relationship between 'the pace of technological innovativeness', 'the perceived ease of use of technology' and 'the perceived usefulness of technology' as well as 'technology anxiety'. At the 
same time, this quantitative study has considered whether socio-demographic variables affected this correlation. The over-arching aim of this research project was to identify and to analyse the determinants which explain why educators are (or are not) engaging themselves in digital technologies. This research project was built on the foundation of the following research questions:

- What are the educator's attitudes about the use of digital learning resources in education?

- Are they actively using digital learning resources in their classrooms? Are they ICT oriented?

\section{Setting the Scene of the Research Environment}

One of the priority areas for the first cycle of the strategic framework for education and training ('ET 2020') is the promotion of creativity and innovation through the use of new ICT tools and teacher training (EU, 2011). ICT transforms teaching and learning as it contributes to the acquisition of basic or key competences. In this day and age, it is imperative that students achieve digital fluency (Smith et al., 2005). "The European Framework for Key Competences for Lifelong Learning" has defined some of the key abilities and subject specific knowledge that individuals need (Halász \& Michel, 2011, EU, 2008). Digital skills and ICT competences are a pre-requisite for employment, personal fulfilment, social inclusion and active citizenship in today's rapidly-changing world (Hoskins \& Crick, 2010; Ross, 2007). In a sense, education institutions are there to help their students develop competences (Halasz \& Michel, 2011). From a tender age, schools teach their pupils to be analytical and reflexive. Students are taught how to work autonomously as well as collaboratively. They learn how to seek information and support as they make use of new resources and technologies (McLoughlin \& Lee, 2010; Fullan, 2008).

National education policy makers have articulated specific policies to use ICT in teaching and learning (ICT in Schools, 2008; European Schoolnet, 2012a). These authorities have implemented support measures to increase the frequency of students' ICT-based activities for learning in the classroom. The EU (2013) survey indicated that the schools that had specific policies about ICT integration in teaching and learning experienced the highest frequency of the use of digital learning resources 
(DLRs) and ICT learning based activities. Furthermore, the report suggested that these schools implemented support measures including teacher professional development and also sought the provision of ICT coordinators. Interestingly, students who attended schools with focused ICT policies were more engaged in DLRs when compared to other students who hailed from schools with no ICT policies or support measures. EU (2013) indicated that on average between 25-30\% of students were in digitally supportive schools as they were developing ICT policies and support measures. Other academic contributions found that the number of digitally supportive schools in Europe was on the rise (Wastiau et al., 2013; Perrotta, 2013). Wastiau et al. (2013) has recommended a combination of several policies and measures on ICT integration in teaching and learning. Notwithstanding, the EU's (2013) report was pushing forward for further decentralisation, in this regard. It recommended that the school heads and their teachers ought to collaborate together and develop peerlearning opportunities. This engagement could also be supplemented with the valuable support from ICT-specialised staff. The stakeholders' efforts are required to reinforce policy and implementation about ICT integration with other subjects.

In Malta there are national strategies covering training measures for ICT in schools, digital / media literacy and e -skills development, training and research projects in elearning, and research projects in e-inclusion (European Schoolnet, 2012b). There are central steering documents for all ICT learning objectives at secondary education level and for using a computer, using office applications, searching for information, and using multimedia at primary level (European Schoolnet, 2012b). ICT is taught as a general tool for other subjects / or as a tool for specific tasks in other subjects. In addition, ICT is taught as a separate subject in secondary schools. Recommendations and support is provided to all primary and secondary schools in all ICT hardware areas, except for mobile devices and e-book readers, and for all ICT software categories. According to official steering documents, both students and teachers at primary and secondary level are expected to use ICT in all subjects both in class and for complementary activities, except for in foreign languages at primary level where it is used only for complementary activities (European Schoolnet, 2012b). There are no central recommendations on the use of ICT in student assessment. Public-private partnerships are increasingly promoting the use of ICT as they are encouraged to use digital technologies. The Ministry for Education and Employment (MEDE) in Malta has recently announced that it is in the process of implementing the 'One tablet per 
child' initiative'. A pilot project is currently underway to assess the use of tablet computing devices in Maltese education.

\section{Digital Learning Resources (DLRs)}

DLRs are often related to the new paradigms of learning (Ling \& Ze, 2011; OECD, 2009). Emerging practices through ICT resources are also consonant with the studentcentred approaches as these innovative resources are personal, social and participatory (McLoughlin \& Lee, 2010). In this light, teachers need to become well acquainted with DLRs (Greenhow \& Robelia, 2009). Teachers are expected to provide guidance, strategic support, and assistance to help students with diverse needs to assume increasing responsibilities for their own learning (Fullan, 2013; Mills, 2010). For instance, many educators are supporting disadvantaged students through DLRs as they help them raise their achievement levels (Mills, 2010).

It may appear that educators at both primary and secondary levels are increasingly recommending a wide range of innovative teaching methods that are based on active and experimental learning (Kolb \& Kolb, 2005). The educators are key players in fostering a new digital environment in schools and colleges. Well-trained teachers should be able to incorporate ICT into their school curricula (Smith et al., 2005). Many academics advocated about the potential of ICT not only as a learning tool but also as a means of assessment (Katz, 2013; Smith et al., 2005). ICT has often been considered as a catalyst for a 'new teaching paradigm', particularly as there is a focus on continuous assessment which is based on learning outcomes (Pedro, 2005:400). Attainment targets usually assess and certify students' ICT skills through practical and / or theoretical tests.

A critical issue facing the promotion of digital learning resources is that assessments of ICT should be coherent across different levels of educational systems (Kozma, 2005). Hence, any changes to extant assessment frameworks may have to reflect the latest developments in teaching and learning, as a result of using ICT in our schools. The educators' personal insights and perceptions of DLRs may also affect the frequency of how students' use ICT resources during their learning journey (Papastergiou, 2009). Teachers are encouraged to use a variety of ICT hardware and software in their classrooms (Smith et al., 2005). It is imperative that teachers keep themselves abreast with the latest developments in ICT. Continuous professional 
development and ongoing training is a prerequisite of an effective and efficient usage of ICT infrastructure. The educators' learning in ICT should be a continuous process as this will enable them to master DLRs during classroom management duties. Therefore, the existence of the latest DLRs in schools is a primary condition for the introduction of innovative teaching methods through the use of interactive software and online materials (Greenhow \& Robelia, 2009).

Cheon et al. (2012) held that mobile learning can also play a significant supplemental role within formal education. These authors held that there are potential benefits of mobile learning including cost savings, ubiquitous communications, study aids, and location-based services. In fact, the U.S. government is seeking to reduce school expenses as it is encouraging the use of digital textbooks rather than paper based text books, within next five years (Hefling \& Feller, 2012). Moreover, students can communicate with other students and their instructors through digital messages on their mobile or digital technologies. Balanskat, Blamire \& Kefala (2006) held that the integration of ICT into school education is a complex process and that it is affected by many different factors. For instance, ICT technologies can play a substantial role in delivering effective school management. In a recent report, the European Commission reiterated that 'embedding ICT in education and training systems requires further changes across the technological, organisational, teaching and learning environments of classrooms, workplaces, and informal learning settings' (EU, 2008; Fullan, 2013; Fullan, 2008).

Evidently, education systems need to adapt to the latest trends to help remedy this situation. Educators may need regular support, professional development programmes and materials in order to keep up-to-date with the latest technological developments (EU, 2013). The researcher believes that EU (2013) is a wake-up call to educational policy makers to invest in training and the professional development of teachers. School heads are encouraged to engage in regular dialogues with teachers and parents for an effective implementation of DLRs (Greenhow \& Robelia, 2009). Fruitful discussions with teaching staff would not only help to increase consensus about the positive implications of having DLRs across all educational levels; but to foster an environment that leads to peer learning opportunities. On the other hand, some of the potential threats to a smooth roll out of DLRs may include; lack of sufficient investments in ICT resources, teachers' incompetence in ICT skills, unclear goals 
(and learning outcomes and course objectives) for using ICT in subjects or a lack of consensus among educational stakeholders (adapted from EU, 2013). Moreover, educators ought to address all vulnerable students who may possess different abilities and / or who may simply not have access to ICT resources at home.

In the main, EU (2013) has shown that students were confident in their digital competences. It seems that students were also positive about the impact of using DLRs in classroom environments. EU (2013:19-20) has also indicated that "such students, having high access / use of ICT at home and at school, are defined in the survey as digitally confident and supportive students". These findings reiterate the importance of using DLRs during lessons at school (Currier, Barton, O’Beirne \& Ryan, 2004). Wastiau et al. (2013) also suggested that students are increasingly becoming more confident in their digital competences, despite lacking access to ICT resources at home. The findings of this report have revealed that there were between $30-35 \%$ of EU students who are "digitally confident and supportive students" (i.e. they have high access to ICT at home and at school). Nevertheless, around 50\% of vocational students at grade 8 and 11 did not have high access / use at home, but had low access / use at school (EU, 2013). This figure decreased to $35 \%$ at grade 11 , in general education. What was quite alarming was that between $18-28 \%$ of students had low access to use ICT at home as well as at school (EU, 2013). These empirical findings are calling for immediate action by educational leaders and policy makers to continue to combine their efforts to increase the number of students who are "digitally confident" and "supportive" (Wastiau et al., 2013; Prensky, 2001, 2005). Perhaps, a systemic approach would be necessary to foster an environment that facilitates digital literacies across all levels of education (EU, 2013; OECD, 2009; Kozma, 2003).

\section{The Formulation of Hypotheses}

Relevant literature suggests that educational institutions are inevitably influenced by the latest advances in technology on teaching and learning. Fullan (2013) held that educators should embrace technologies and apply them in meaningful ways to positively impact students. He advocated the connections and disconnections between pedagogy, technology, and change knowledge in education. Fullan (2013) went on to suggest that a "new pedagogy" of higher-order skills that focuses on the harnessing of fast and innovative technologies can bring about change in the right direction (for the delivery of student-centred education). 


\section{Pace of Technological Innovativeness}

The educators' personal insights and perceptions of DLRs may also affect the frequency of how students' engage themselves in education. Garcia and Calantone (2002) maintained that the innovation process comprises the technological development of an invention combined with the market introduction of that invention to end users through adoption and diffusion. They claimed that the pace of technological innovativeness is 'iterative' as it involves continuous engagement with new emerging innovations. Therefore, teachers ought to keep themselves abreast with the latest technological innovations (Greenhow \& Robelia, 2009). At the same time, the schools should remain up-to-date with the latest ICT infrastructure (EU, 2013). Continuous professional development and ongoing training is a prerequisite of an effective and efficient use of ICT infrastructure and digital learning resources (Wastiau et al., 2013; Prensky, 2001, 2005). This leads to the first hypothesis:

i. There is a relationship between 'the pace of technological innovation' in schools and 'the technological acceptance' of educators.

\section{The Technology Acceptance Model and Technological Anxiety}

The technological acceptance model has been frequently used to explain the users' adoption behaviours of technology (Davis, 1989; Davis, Bagozzi \& Warshaw, 1989). This purported model has explained the causal relationship between users' internal beliefs, attitude, intentions and computer usage behaviours. In the past, the technological acceptance model sought to explain why people accept or reject a particular technology (Davis, 1989). Therefore, the technological acceptance model has been used for this research to find out why educators accept or reject digital learning resources. Davis (1989) suggested that perceived usefulness is the degree to which a person believes that using a particular system would enhance his or her job performance. From the outset, the researchers presumed that the Maltese educators would perceive usefulness and ease of use of digital learning resources in their classroom environments.

Notwithstanding, Davis (1989) explained that perceived ease of use (PEOU) was "the degree to which a person believes that using a particular system would be free of effort" (Davis, 1989, p. 320). Davis (1989) held that usage is influenced by perceived 
ease of use. In this case, the researchers investigated whether the educators at St Clare's were (or were not) proficient in the use of digital learning technologies. Although potential users may believe that a given technology is useful, they may, at the same time be averse in using such resources. They may perceive that systems may be too hard to use and that the performance benefits of usage are outweighed by the effort of using such applications (Meuter et al., 2005; Garcia \& Calantone, 2002). This leads to the second and third hypotheses: the 'pace of technological innovativeness' (De Smet et al., 2012; Grewal et al., 2004); 'technology acceptance' (Jackson et al., 2013; Cheon et al., 2012; Huang et al., 2012; Davis, 1989) and 'technology anxiety' (Celik \& Yesilyurt, 2013; Tondeur et al., 2012); Meuter et al., 2005).

ii. There is a positive relationship between perceived usefulness and the perceived ease of use of digital learning resources. (This hypothesis investigates the technological acceptance model in the Maltese context)

iii. $\quad$ This empirical study will also investigate the causal relationships (by using stepwise regression) between perceived usefulness, perceived ease of use, the pace of technological innovativeness and technological anxiety.

\section{Methodology}

This study has targeted all members of staff including heads, assistant heads, teachers and learning support assistants in eleven schools at St Clare's College in Malta. The survey was distributed by email to administrative secretaries (or assistant heads) that in turn forwarded the survey link to all educators in their respective school. This method was characterised by the limited contact between the researcher and the informants. The lack of personal involvement has reinforced the objectivity of this research. Nevertheless, the questionnaires have constituted an efficient and economical way of collecting responses from relatively large samples (Saunders, Lewis \& Thornhill, 2009. Subsequently, the completed surveys were either submitted online or printed and returned to the researcher.

\section{The Socio-Demographic Profile}

The surveyed respondents gave their socio-demographic details about their 'gender', 'age', 'role', 'experience' and 'educational background' in the latter part of the survey questionnaire. The objective of this designated profile of educators was to gain an insight into their attitudes and perceptions on ICT. Table 1 presents the profile of educators that participated in this study: 
Table 1. The socio-demographic profile of the survey participants

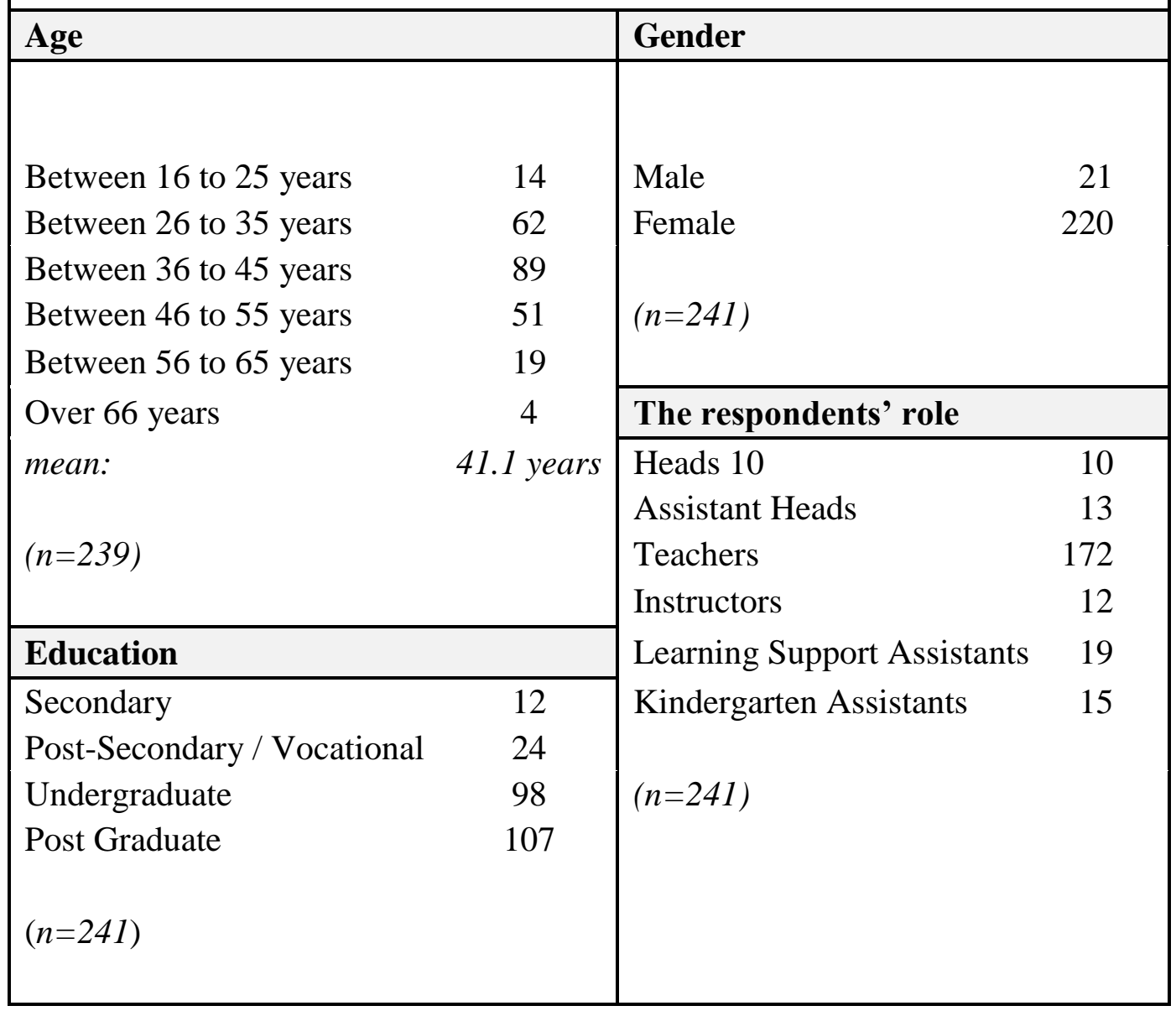

There were twenty one males (9\%) and two hundred twenty females $(91 \%) \quad(n=241)$. Again, the respondents' 'age' varied, and this was evident in the standard deviation $(\boldsymbol{\sigma})$ of 0.70 . Respondents were also classified into five age groups $(16-25$; 26-35; 3645; 46-55 and 56-65). The majority of the respondents were aged between 36 and 45 years of age $(37 \%, \mathrm{n}=89)$, followed by those aged between 26 and 35 years $(26 \%$, $\mathrm{n}=62$ ). The designation / 'role' of the respondents taking part in this study consisted of heads $(4.1 \%, \mathrm{n}=10)$, assistant heads $(5.4 \%, \mathrm{n}=13)$, teachers $(71.4 \%, \mathrm{n}=172)$, instructors $(5 \%, \mathrm{n}=12)$, facilitators $(7.9 \%, \mathrm{n}=19)$ and kindergarten assistants $(6.2 \%$, $\mathrm{n}=15)$. All the respondents were full time educators and held an indefinite engagement contract with the Ministry of Education and Employment in Malta. The respondents' mean $(\overline{\boldsymbol{Z}})$ 'work experience within the education sector' was 
approximately fifteen years. The responses ranged from a minimum of a year to a maximum of thirty one years of relevant industry experience. The majority of respondents indicated that they attended tertiary education $(85.1 \%, \mathrm{n}=205)$. Whereas, twenty four respondents $(9.9 \%)$ attended vocational institutions and twelve individuals (5\%) indicated that they completed the secondary 'level of education'.

\section{The Measures}

The questionnaires contained standardised, pre-coded answers. Such instruments have frequently been used to identify and describe various phenomena, and to shed light on the relationships between constructed variables. Saunders et al. (2009) indicated that the validity and reliability of the gathered data depended on the questionnaire design and its structure.

Technological innovation is currently proceeding at an unprecedented pace in education. A thorough literature review suggested that digital innovations are stimulated by a desire to improve the quality of teaching and learning which also resonates with student-centred education (Sang, Valcke, van Braak and Tondeur, 2010; Drent \& Meelissen, 2008; Hannafin, Hill \& Land, 1997). Recently, there has been extensive and systemic technological change in the realms of education (Fullan, 2013). Therefore, the researcher has adapted six items from the 'pace of technological innovation'; that intended to measure the educators' attitudes toward digital learning resources. Originally, this scale has reported a construct reliability of 0.97 (Grewal et al., 2004) and had used confirmatory factor analysis to provide evidence to support the scales' convergent and discriminant validities.

The technological acceptance model has played an important role in the successful development of e-learning systems (Chatzoglou, Sarigiannidis, Vraimaki \& Diamantidis, 2009, Liu, Chen, Sun, Wible \& Kuo, 2010 and Sanchez-Franco, 2010). This model was developed by Davis (1989) and it has become a popular means by which to evaluate user perspectives on the perceived ease of use, perceived usefulness, attitude toward use and behavioral intention. Perceived ease of use (PEoU) refers to a person's belief that using a technology will be free of effort (Davis, 1989). Perceived usefulness (PU) refers to a person's belief that using a technology will enhance his / her job performance (Davis, 1989). 
The PEoU and PU items were adapted from Davis (1989) 'technological acceptance model'. Perceived ease of use measured 'the degree to which a person believes that using a particular system would be free of effort" (Davis, 1989, p. 320) and contained six measurement items. The definition of 'perceived usefulness' also comprised six items. The PU scale attained a constructed reliability of 0.97 , while PEoU achieved a reliability of 0.91 (Davis, 1989). The scale was acceptable as the factor loadings were reported to be significant and evidence of discriminant validity was provided for each construct.Four items were used to measure the degree to which an educator is apprenhensive about the usage of digital learning resources (Meuter et al., 2005) These items were also similar to the computer anxiety scale that were used by Celik \& Yesilyurt (2013) that originally consisted of 28 items and 4 factors as affective anxiety toward computers, fear of damaging computers, fear of learning to use computers and sense of confidence toward computers. Meuter et al.'s (2005) construct was also synonymous with the term 'technophobia' (see Brosnan, 1998; Rosen, Sears $\&$ Weil, 1987). Meuter et al. (2005) reported an alpha of 0.93 in both of their studies. The authors tested a measurement model containing all of their constructs and indicators. Its fit was acceptable as the factor loadings were reported to be significant. There was evidence of discriminant validity for each construct using different tests (confidence interval and variance exctracted).

\section{Data Analysis and Interpretation of the Findings}

The survey questionnaires' responses were imported directly into SPSS. After filtering data responses and eliminating unusable or incomplete survey observations, a total of 241 valid responses were obtained. Reliability and appropriate validity tests have been carried out during the analytical process. Cronbach's alpha was calculated to test for the level of consistency among the items. Alpha was 0.85. This figure indicated an acceptable level of reliability.

\section{Univariate Statistics}

All the responses were coded using a five point likert scaling mechanism. The values ranged from 1 (strongly disagree) to 5 (strongly agree) with 3 signalling indecision. Descriptive statistics have been presented for each variable, hereunder. The educators were required to indicate their level of agreement with the survey questionnaires' statements. In their first question the respondents indicated their frequency of use of the personal computer, laptop, netbook and mobile / smart phone technologies. It 
transpired that they frequently used the laptop. In fact, there was a mean $(\overline{\mathbf{Z}})$ of 3.77 and a standard deviation $(\boldsymbol{\sigma})$ of 0.85 . On the other hand, there was a low mean $(\overline{\boldsymbol{x}})$ score of 1.08 and a standard deviation $(\boldsymbol{\sigma})$ of 0.36 for netbooks. Table 1 indicates the descriptive statistics for 'pace of technological innovativeness', 'perceived ease of use', 'perceived usefulness' and 'technological anxiety' variables.

Table 2: Descriptive Statistics of the Measures

\begin{tabular}{|c|c|c|c|}
\hline Variable & Items & Mean & $\begin{array}{l}\text { Std. } \\
\text { Dev. }\end{array}$ \\
\hline $\begin{array}{l}\text { Pace of Technological } \\
\text { Innovativeness }\end{array}$ & $\begin{array}{l}\text { Digital Technologies are changing at a very fast } \\
\text { pace. } \\
\text { Compared to other digital products, learning } \\
\text { technologies are changing fast. } \\
\text { I have consistently seen new technology in } \\
\text { education for some time. } \\
\text { Innovations in education are frequent. } \\
\text { The pace of technological innovations in } \\
\text { education is high. } \\
\text { Technological innovations and education don't } \\
\text { go hand in hand. }\end{array}$ & $\begin{array}{l}4.6809 \\
4.0496 \\
3.9574 \\
3.9362 \\
3.2057 \\
2.2979\end{array}$ & $\begin{array}{l}.53877 \\
.46792 \\
.37554 \\
.53736 \\
.47083 \\
.70452\end{array}$ \\
\hline $\begin{array}{l}\text { Perceived Ease } \\
\text { Of Use }\end{array}$ & $\begin{array}{l}\text { Learning to operate digital learning resources } \\
\text { would be easy for me. } \\
\text { I would find it easy to use digital learning } \\
\text { resources during classroom activities. } \\
\text { My interaction with the digital learning resources } \\
\text { would be clear and understandable for students. } \\
\text { I would find digital learning resources to be } \\
\text { flexible to interact with. } \\
\text { It would be easy for me to become skilful at } \\
\text { using digital learning resources. } \\
\text { I would find digital learning resources easy to } \\
\text { use. }\end{array}$ & $\begin{array}{l}3.8227 \\
3.2199 \\
3.8652 \\
3.8156 \\
3.8652 \\
3.9574\end{array}$ & $\begin{array}{l}.58899 \\
.53575 \\
.34268 \\
.40713 \\
.53745 \\
.39411\end{array}$ \\
\hline $\begin{array}{l}\text { Perceived } \\
\text { Usefulness }\end{array}$ & $\begin{array}{l}\text { Using digital learning resources would enable } \\
\text { me to accomplish tasks more quickly. } \\
\text { Using digital learning resources would improve } \\
\text { my job performance. } \\
\text { Using digital learning resources would enhance } \\
\text { my effectiveness on the job. } \\
\text { Using digital learning resources would make it } \\
\text { easier to do my job. } \\
\text { I would find digital learning resources useful in } \\
\text { my job. } \\
\text { Learning to operate digital learning resources } \\
\text { would be easy for me. }\end{array}$ & $\begin{array}{l}3.7872 \\
3.9078 \\
3.9645 \\
3.9149 \\
3.9929 \\
3.9504 \\
3.7872\end{array}$ & $\begin{array}{l}.41072 \\
.29034 \\
.38566 \\
.28003 \\
.28022 \\
.34489 \\
.41072\end{array}$ \\
\hline $\begin{array}{l}\text { Technological } \\
\text { Anxiety }\end{array}$ & $\begin{array}{l}\text { I feel apprehensive about using digital learning } \\
\text { resources. } \\
\text { Technical terms sound like confusing jargon to } \\
\text { me. }\end{array}$ & $\begin{array}{l}2.7163 \\
2.8865\end{array}$ & $\begin{array}{l}.45239 \\
.44868\end{array}$ \\
\hline
\end{tabular}


This study is consistent with the extant literature on the technology acceptance model' (Jackson et al., 2013; Cheon et al., 2012; Huang et al., 2012; Davis, 1989; Davis et al., $1989)$. As a matter of fact, there were high mean scores $(\overline{\boldsymbol{X}})$ of near 4 , which reflected the educators' stance on the use of digital learning resources'. Moreover, the respondents have conveyed their strong agreement with the 'pace of technological innovativeness' (De Smet et al., 2012; Grewal et al., 2004). The educators suggested that learning technologies are changing fast, where the mean score $(\overline{\boldsymbol{X}})$ was of 4.05 and a standard deviation $(\boldsymbol{\sigma})$ of 0.47 . Unsurprisingly, there was no disagreement whatsoever, regarding these issues.

\section{Data Reduction}

The value of the Kaiser Meyer Olkin (KMO) measure of sampling adequacy was acceptable at 0.9. Bartlett's test of sphericity also revealed sufficient correlation in the dataset to run a principal component analysis (PCA) since $p<0.001$. PCA has been chosen to obtain a factor solution of a smaller set of salient variables, from a much larger dataset. A varimax rotation method was used to spread variability more evenly amongst the constructs.

PCA was considered appropriate as there were variables exhibiting an underlying structure. Many variables shared close similarities as there were highly significant correlations. Therefore, PCA has identified the patterns within the data and expressed it by highlighting the relevant similarities (and differences) in each and every component. In the process, the data has been compressed as it was reduced in a number of dimensions without much loss of information. The rationale for the data reduction was to have in place the factor components for the subsequent multivariate regression analysis. From SPSS; the principal component analysis has produced a table which illustrated the amount of variance in the original variables (with their respective initial eigenvalues) which were accounted for by each component. There was also a percentage of variance column which indicated the expressed ratio, as a percentage of the variance (accounted for by each component to the total variance in all of the variables). A brief description of the extracted factor components, together 
with their eigenvalue and their respective percentage of variance is provided hereunder in Table 2 . With respect to scale reliability, all constructs were analysed for internal consistency by using Cronbach's alpha. The composite reliability coefficient (Bagozzi, and Yi, 1988) was 0.884, well above the minimum acceptance value of 0.7

Table 3 The Extracted Factor Components

\begin{tabular}{|c|c|c|c|c|c|c|c|}
\hline & \multirow[b]{2}{*}{$\begin{array}{l}\text { Factor } \\
\text { Component }\end{array}$} & \multicolumn{2}{|c|}{ Initial Eigenvalues } & \multicolumn{2}{|c|}{$\begin{array}{l}\text { Extraction Sums of } \\
\text { Squared Loadings }\end{array}$} & \multicolumn{2}{|c|}{$\begin{array}{l}\text { Rotation Sums of } \\
\text { Squared Loadings }\end{array}$} \\
\hline & & Total & $\begin{array}{c}\% \text { of } \\
\text { Variance }\end{array}$ & Total & $\begin{array}{c}\% \text { of } \\
\text { Variance }\end{array}$ & Total & $\begin{array}{c}\% \text { of } \\
\text { Variance }\end{array}$ \\
\hline 1 & $\begin{array}{l}\text { Perceived } \\
\text { Usefulness of } \\
\text { DLR }\end{array}$ & 5.533 & 25.152 & 5.533 & 25.152 & 4.04 & 18.362 \\
\hline 2 & $\begin{array}{l}\text { Pace of } \\
\text { Technological } \\
\text { Innovation }\end{array}$ & 2.378 & 10.809 & 2.378 & 10.809 & 2.555 & 11.613 \\
\hline 3 & $\begin{array}{l}\text { Technological } \\
\text { Anxiety }\end{array}$ & 1.846 & 8.391 & 1.846 & 8.391 & 2.27 & 10.319 \\
\hline 4 & $\begin{array}{l}\text { Easy } \\
\text { Interaction } \\
\text { with DLR }\end{array}$ & 1.662 & 7.553 & 1.662 & 7.553 & 1.711 & 7.776 \\
\hline 5 & $\begin{array}{l}\text { Perceived } \\
\text { Ease of Use } \\
\text { of DLR }\end{array}$ & 1.192 & 5.418 & 1.192 & 5.418 & 1.681 & 7.642 \\
\hline 6 & Effective DLR & 1.119 & 5.085 & 1.119 & 5.085 & 1.473 & 6.695 \\
\hline 7 & & 0.995 & 4.524 & & & & \\
\hline 8 & & 0.886 & 4.028 & & & & \\
\hline 9 & & 0.829 & 3.767 & & & & \\
\hline 10 & & 0.775 & 3.523 & & & & \\
\hline 11 & & 0.68 & 3.092 & & & & \\
\hline 12 & & 0.651 & 2.958 & & & & \\
\hline 13 & & 0.611 & 2.778 & & & & \\
\hline 14 & & 0.487 & 2.214 & & & & \\
\hline 15 & & 0.421 & 1.914 & & & & \\
\hline 16 & & 0.409 & 1.858 & & & & \\
\hline 17 & & 0.384 & 1.747 & & & & \\
\hline 18 & & 0.319 & 1.452 & & & & \\
\hline 19 & & 0.271 & 1.23 & & & & \\
\hline 20 & & 0.24 & 1.09 & & & & \\
\hline 21 & & 0.215 & 0.976 & & & & \\
\hline 22 & & 0.097 & 0.442 & & & & \\
\hline
\end{tabular}

Extraction Method: Principal Component Analysis.

Alpha $=0.884 ; \mathrm{KMO}=0.771 ; \mathrm{df} 231 ;$ Sig: .000 
The sum of the eigenvalues equalled the number of components. Only principal components with eigenvalues greater than 1 were extracted. The factors accounted for more than $62 \%$ variance before rotation. There were six extracted components from twenty-two variables. The factor components were labelled following a crossexamination of the variables with the higher loadings. Typically, the variables with the highest correlation scores had mostly contributed towards the make up of the respective component. The underlying scope of combining the variables by using component analysis was to reduce the data and make it more adaptable for regression analysis.

\section{Multivariate Regression Analysis}

A stepwise procedure was purposely carried out to select the most relevant predictive variables in the regression models. The $p$-value was less than the 0.05 benchmark. There were adequate F-ratios, implying that significant amounts of variation in regression were accounted for. More importantly, in the stepwise procedure the insignificant variables were excluded without appreciably increasing the residual sum of squares (Field, 2009). The regression models produced the regression coefficients which represented the strength and significance of the relationships. Moreover, the control variables, namely 'age' and 'gender' were also entered into the equations.

Initially, the first factor component; namely, perceived usefulness was inserted as the outcome variable. All the other five factor components as well as the variables of "age" and "gender" were inserted as independent variables in the stepwise regression equation. The results indicated that there was a positive and significant relationship between perceived usefulness of the digital learning resources and the respondents' age where Spearman's rank correlation coefficient was 0.265 (Spearman's rho). This relationship was significant at $(p<0.05)$. It transpired that the 'perceived usefulness' was dependent on the respondents' age $(\mathrm{F}=10.457)$.

Two regression equations were inconclusive when the factor components; namely, 'pace of technological innovation' and 'easy interaction' with DLRs were inserted as the dependent variables and all the other factor components were entered as independent variables (along with the 'age' and 'gender' variables). 
Afterwards, the factor component; namely, 'technological anxiety' was inserted as the dependent variable and all the other five factor components were considered as possible antecendents (in the stepwise regression equation) the results indicated that there was a positive and significant relationship between 'technological anxiety' in using digital learning resources and 'age' where Spearman's rho was 0.217. This relationship was very significant at $(p<0.01)$ and $\mathrm{F}=6.872$.

Again, the stepwise regression indicated a positive and significant relationship between 'perceived ease of use of DLR' and the 'gender' variable. In this case, Spearman's rho was 0.191. This relationship was significant at $(p<0.05)$ and the analysis of the variance; the F statistic was 5.274.

When the factor component, 'effective use of DLR' was inserted as a dependent variable in the regression equation, the stepwise regression indicated that the 'age'variable was its antecedent. There was a positive and highly significant relationship ( $p>0.001)$. Spearman's rho was 0.293 . This equation shows that that an effective use of digital learning resources was dependent on the respondents' age ( $\mathrm{F}=$ 13.084).

In conclusion, the stepwise regression analysis indicated that this study's hypotheses were all negative as there was no relationship between perceived usefulness and the perceived ease of use of digital learning resources in Maltese education. Moreover, there was no positive and significant relationship between perceived usefulness, perceived ease of use, the pace of technological innovativeness and technological anxiety. Nevertheless, this empirical study revealed that the acceptance of digital learning resources in education was affected by gender and the age of respondents.

\section{Discussion}

This research has reinforced the literature revolving on the use of digital learning resources in education. It has addressed its research objectives and implicit hypotheses by using quantitative techniques to unfold the pros and cons of utilising digital technologies in the realms of education. This empirical study has applied measures from the 'pace of technological innovativeness' (De Smet et al., 2012; Grewal et al., 2004); 'technology acceptance' (Jackson et al., 2013; Cheon et al., 2012; Huang et al., 2012; Davis, 1989) and 'technology anxiety' (Celik \& Yesilyurt, 
2013; Tondeur et al., 2012; Meuter et al., 2005). A summary of the statistics has described the socio-demographic profile of the respondents, as the descriptive statistics have unfolded the educators' attitudes and perceptions about the costs and benefits of digital learning resources. This study investigated the causal relationships between perceived ease of use, perceived usefulness, the pace of technological innovativeness and technological anxiety. Moreover, it explored whether there were any socio-demographic variables that led to the technology acceptance by educators. The quantitative results have indicated that there were positive and highly significant relationships between the effective use of digital learning resources and the respondents' age. In addition, there were significant relationship between the perceived usefulness of the digital learning resources and the respondents' age; between 'technological anxiety' in using digital learning resources and 'age' and between perceived ease of use and gender.

This study has shed light on the teachers' engagement with digital learning technologies. It has evaluated how these electronic resources and other innovations such as mobile technologies are affecting the quality of education in Malta. The literature review has indicated what provisions could be required for a smooth rollout of ICT resources, including tablet technologies and smart applications. The research project has also identified and analysed the determinants which explain the rationale for the utilisation of digital learning technologies in education. Previous academic research may have paid limited attention to the engagement of ICT by Maltese educators (Lauri, Borg, Günnel \& Gillum, 2010 Mayo, Pace \& Zammit, 2008). Arguably, the use of digital media could be viewed as a critical success factor in education. It may possibly lead to an increased engagement in information and communication technologies and in improved learning outcomes. Accordingly, educational software designers may create specific apps that appeal to students in order to help them in their educational programmes (Kinshuk, Spector \& Schrum, 2007).

This study has shown that educators were aware that they ought to adapt their educational methodologies to today's realities. Evidently, they admitted that they were already using digitally-mediated resources in their lessons. However, the educators also indicated that they were not extremely confident on how to use certain 
technologies in their lessons. The results suggest that teachers may require continuous professional development and training in this regard. The researcher believes that there is scope for educators to consider the results of this research, as ongoing investments in digital infrastructures will often result in improved engagement levels by teachers and students (Wastiau et al., 2013; Perrotta, 2013; Prensky, 2005, 2001). As the educators become increasingly acquainted with digital learning resources, they is an opportunity to enhance their proficiency levels and expertise.

\section{Research Limitations}

This research project has investigated the educators' attitudes on ICT in education. Although there were two hundred forty-one research participants for this quantitative study, this only represented a quarter of the stratified sample of educators that were members of staff at St Clare College. Although the number of survey participants was sufficient in drawing conclusions about the educators' attitudes on the use of digital learning resources in Malta; this study is not amenable in drawing general conclusions in other contexts. In addition, the researcher believes that there is scope in undertaking face to face interviews with educational leaders including heads and assistant heads, as they may raise different concerns. Of course, there can be different digital literacies across other schools.

The extensive literature review has also revealed that there were many constructs pertaining to technologies in education. Evidently, there is a wide array of digital learning resources that may be used in classroom activities. The lack of uniformity and consistency on the terms that describe digital learning resources has made it difficult to compare results across previous studies. In addition, previous studies may have considered different sampling frames, research designs, methodologies and analyses which could have produced different outcomes (Davis, 1989; Davis et al., 1989; Jackson et al., 2013; Cheon et al., 2012; Huang et al., 2012; Celik \& Yesilyurt, 2013; Tondeur et al., 2012). Moreover, this research area is attracting researchers from heterogeneous backgrounds; bringing different values, ideologies and perspectives in shaping and formulating the use of electronic resources in curriculum programmes. Therefore, this study had a number of limitations that may have somewhat circumscribed the interpretation of the findings.

\section{Implications of this study}


The findings of this study ought to be supported by further research on digital learning resources, including game-based learning and digital stories in other contexts. Other academics have also posited that electronic games are a purposive technology and that they are increasingly being associated with learning (Kinshuk et al., 2007). Digital games can bring positive effects on students (Graesser, Chipman, Leeming and Biedenbach, 2009; Yee, 2006; Prensky 2006, 2005; Virvou, Katsionis \& Manos, 2005; Squire, 2003). Perhaps, further research can specifically investigate the motivational appeal of digital games in supporting educational outcomes (Warren et al., 2008). Moreover, there is scope in analysing the designs of electronic games and digital stories in terms of their complexities and sophistication levels in order to improve on extant learning resources. This issue could be carried out by closely monitoring the student behaviours as they engage themselves in digital learning. This contribution indicated that certain digital apps may supplement the learning objectives of syllabi. Digital resources can be employed in different subject matters, within scholastic environments, in many contexts. In addition, future studies may possibly unfold how such educational apps can support individual students in their learning journeys. Empirical findings may reveal that there may be diverse motivations in favour or against digital learning among different demographics. For example, the individual students' gender, age as well as their position in the social strata may affect their disposition to using digital games to learn subjects. A longitudinal study in this area of research could possibly investigate the benefits of digital learning resources in education and establish its effects in the long term.

\section{References}

Bagozzi, R. P., \& Yi, Y. (1988). On the evaluation of structural equation models. Journal of the academy of marketing science, 16(1), 74-94.

Balanskat, A., Blamire, R., and Kefala, S., 2006. The ICT impact report. European Schoolnet. Available from http://ec.europa.eu/education/pdf/doc254_en.pdf [Accessed on $20^{\text {th }}$ September 2011].

Bocconi, S., Kampylis, P. and Punie, Y., 2013. Framing ICT-enabled Innovation for Learning: the case of one-to-one learning initiatives in Europe. European Journal of Education. 48: 113-130. 
Brosnan, M. J., 1998. The impact of computer anxiety and self-efficacy upon performance. Journal of computer assisted learning, 14(3), 223-234.

Burns, M., 2013. Success, Failure or no Significant Difference: Charting a Course for Successful Educational Technology Integration. International Journal of Emerging Technologies in Learning. 8(1), 38-45.

Castaño-Muñoz, J., Duart, J. M., \& Sancho-Vinuesa, T. 2014. The Internet in face-toface higher education: Can interactive learning improve academic achievement?. British Journal of Educational Technology, 45(1), 149-159.

Celik, V. and Yesilyurt, E., 2013. Attitudes to technology, perceived computer selfefficacy and computer anxiety as predictors of computer supported education. Computers \& Education, 60(1), 148-158.

Chatzoglou, P. D., Sarigiannidis, L., Vraimaki, E., \& Diamantidis, A. (2009). Investigating Greek employees' intention to use web-based training. Computers \& Education, 53(3), 877-889.

Cheon, J., Lee, S., Crooks, S. M., and Song, J., 2012. An investigation of mobile learning readiness in higher education based on the theory of planned behavior. Computers \& Education, 59(3), 1054-1064.

Davis, F.D., 1989. Perceived usefulness, perceived ease of use, and user acceptance of information technology. MIS quarterly, 319-340.

Davis, F.D., Bagozzi, R.P. and Warshaw, P.R., 1989. User acceptance of computer technology: a comparison of two theoretical models. Management science, 35 (8), 982-1003.

De Smet, C., Bourgonjon, J., De Wever, B., Schellens, T. and Valcke, M., 2012. Researching instructional use and the technology acceptation of learning management systems by secondary school teachers. Computers \& Education, 58, 688-696. 
Drent, M. and Meelissen, M., 2008. Which factors obstruct or stimulate teacher educators to use ICT innovatively? Computers \& Education, 51(1), 187-199.

EU, 2008. The use of ICT to support innovation and lifelong learning for all - A report on progress. European Commission, Brussels. Available from:

http://www.europarl.europa.eu/registre/docs_autres_institutions/commission_europee nne/sec/2008/2629/COM_SEC\%282008\%292629_EN.pdf [Accessed 25th May 2014].

EU, 2011. Key Data on Learning and Innovation through ICT at School in Europe. Education, Audiovisual and Culture Executive Agency, European Commission, Brussels. Available from: http://eacea.ec.europa.eu/education/eurydice/documents/key_data_series/129en.pdf [Accessed 13th May 2014].

EU, 2013. Survey of schools: ICT in Education, Digital Agenda for Europe.

Publications Office of the European Union, Luxembourg.

European Schoolnet, 2012a. Survey of Schools: ICT in Education. Available from: http://essie.eun.org/ [Accessed 12th June 2014].

European Schoolnet, 2012b. Survey of Schools: ICT in Education. Country Profile Malta. Available from: https://ec.europa.eu/digital-agenda/sites/digitalagenda/files/Malta\%20country\%20profile.pdf [Accessed 15th June 2014].

Field, A., 2009. Discovering statistics using SPSS. Sage publications.

Fullan, M., and Smith, G. 1999. Technology and the problem of change. Available from http://www. michaelfullan. ca. Articles_98-99/12_99. Pdf [Accessed 10 ${ }^{\text {th }}$ March 2014].

Fullan, M., 2008. The new meaning of educational change (4th ed.). London, Routledge.

Fullan, M., 2013. Stratosphere: Integrating technology, pedagogy, and change knowledge. Don Mills, Canada: Pearson. 
Garcia, R. and Calantone, R., 2002. A critical look at technological innovation typology and innovativeness terminology: a literature review. Journal of product innovation management, 19(2), 110-132.

Graesser, A., Chipman, P., Leeming, F. and Biedenbach, S., 2009. Deep learning and emotion in serious games. Serious games: Mechanisms and effects, 83-102.

Greenhow, C., and Robelia, B., 2009. Old communication, new literacies: Social network sites as social learning resources. Journal of Computer-Mediated Communication, 14(4), 1130-1161.

Grewal, R., Mehta, R. and Kardes, F. R., 2004. The timing of repeat purchases of consumer durable goods: The role of functional bases of consumer attitudes. Journal of Marketing Research, 41(1), 101-115.

Halász, G. and Michel, A., 2011. Key Competences in Europe: interpretation, policy formulation and implementation. European Journal of Education, 46(3), 289-306.

Hannafin, M. J., Hill, J. R. and Land, S. M., 1997. Student-Centered Learning and Interactive Multimedia: Status, Issues, and Implications. Contemporary Education, 68(2), 94-97.

Harkema, S. J., and Schout, H., 2008. Incorporating Student-Centred Learning in Innovation and Entrepreneurship Education. European Journal of Education, 43(4), 513-526.

Hefling, K. and Feller, B., 2012. No Child Left Behind: 10 states receive waivers from education law's sweeping requirements. NBCNews. Available from: http://www.nbcnews.com/id/46323704/ns/politics/t/official-states-given-waiver-nochild-left-behind-learning-laws\#.VUcgnfBNqCk [Accessed on $1^{\text {st }}$ February 2015].

Hoskins, B. and Crick, R.D., 2010. Competences for learning to learn and active citizenship: different currencies or two sides of the same coin? European Journal of Education, 45(1), 121-137. 
Huang, Y. M., Huang, Y. M., Huang, S. H. and Lin, Y. T., 2012. A ubiquitous English vocabulary learning system: Evidence of active/passive attitudes vs. usefulness/ease-of-use. Computers \& Education, 58(1), 273-282.

ICT in Schools, 2008. Investing effectively in Information and Communications Technology in Schools. A report of the Irish minister's strategy group. Available from https://www.education.ie/en/Publications/Policy-Reports/Investing-Effectively-inInformation-and-Communication-Technology-in-Schools-2008-2013.pdf [Accessed 20th June 2014].

Jackson, J. D., Mun, Y. Y. and Park, J. S., 2013. An empirical test of three mediation models for the relationship between personal innovativeness and user acceptance of technology. Information \& Management, 50(4), 154-161.

Katz, I. R., 2013. Testing information literacy in digital environments: ETS's iSkills assessment. Information technology and Libraries, 26(3), 3-12.

Kinshuk, S. P., Spector, JM and Schrum, L. 2007. Special issue introduction: A critical view of technology-enhanced learning and instruction in the digital age. Journal of Research on Technology in Education, 40(1), 2-3.

Kolb, A. Y. and Kolb, D. A., 2005. Learning styles and learning spaces: Enhancing experiential learning in higher education. Academy of management learning \& education, 4(2), 193-212.

Kozma, R. B., 2003. Technology and classroom practices: An international study. Journal of Research on Technology in Education, 36(1), 1-14.

Kozma, R. B., 2005. National policies that connect ICT-based education reform to economic and social development. Human Technology: An interdisciplinary journal on humans in ICT environments, 1(2), 117-156. 
Lauri, M. A., Borg, J., Günnel, T., \& Gillum, R. (2010). Attitudes of a sample of

English, Maltese and German teachers towards media education. European Journal of Teacher Education, 33(1), 79-98.

Ling, P., and Ze, Z., 2011. Developing Digital Learning Resources for the College Market in China. Publishing research quarterly, 27(4), 354-363.

Liu, I. F., Chen, M. C., Sun, Y. S., Wible, D. and Kuo, C. H., 2010. Extending the TAM model to explore the factors that affect Intention to Use an Online Learning Community. Computers \& Education, 54(2), 600-610.

Mayo, P., Pace, P. J., \& Zammit, E. (2008). Adult education in small states: the case of Malta. Comparative Education, 44(2), 229-246.

McLoughlin, C. and Lee, M. J., 2010. Personalised and self regulated learning in the Web 2.0 era: International exemplars of innovative pedagogy using social software. Australasian Journal of Educational Technology, 26(1), 28-43.

Meuter, M. L., Bitner, M. J., Ostrom, A. L. and Brown, S. W., 2005. Choosing among alternative service delivery modes: An investigation of customer trial of self-service technologies. Journal of Marketing, 69(2), 61-83.

Mills, K. A., 2010. A review of the "digital turn" in the new literacy studies. Review of Educational Research, 80(2), 246-271.

NMC, 2012. A National Minimum Curriculum Framework For All. Ministry of Education and Employment, Malta. Available at http://curriculum.gov.mt [Accessed on the 29th July 2014].

OECD, 2009. Beyond Textbooks: Digital Learning Resources as Systemic Innovation in the Nordic Countries Centre for Educational Research and Innovation. Available from http://www.oecd-ilibrary.org.ezproxy1.bath.ac.uk/education/beyondtextbooks_9789264067813-en [Accessed on 12 ${ }^{\text {th }}$ December 2014]. 
Papastergiou, M. (2009). Digital game-based learning in high school computer science education: Impact on educational effectiveness and student motivation. Computers \& Education, 52(1), 1-12.

Pedró, F., 2005. Comparing traditional and ICT-Enriched university teaching methods: Evidence from two empirical studies. Higher Education in Europe, 30(3-4), 399-411.

Perrotta, C., 2013. Do school-level factors influence the educational benefits of digital technology? A critical analysis of teachers' perceptions. British Journal of Educational Technology, 44(2), 314-327.

Prensky, M., 2001. Digital natives, digital immigrants part 1. On the horizon, 9(5), 16.

Prensky, M., 2005. Computer games and learning: Digital game-based learning. Handbook of computer game studies, 18, 97-122.

Prensky, M., 2006. Don't Bother Me, Mom, I'm Learning!: How Computer and Video Games are Preparing Your Kids for 21st Century Success and how You Can Help!. New York: Paragon House.

Rosen, L. D., Sears, D. C., and Weil, M. M., 1987. Computerphobia. Behavior Research Methods, Instruments, \& Computers, 19(2), 167-179.

Ross, A., 2007. Multiple identities and education for active citizenship. British Journal of Educational Studies, 55(3), 286-303.

Sang, G., Valcke, M., van Braak, J., and Tondeur, J., 2010. Student teachers' thinking processes and ICT integration: Predictors of prospective teaching behaviors with educational technology. Computers \& Education, 54(1), 103-112.

Sardone, N. B., and Devlin-Scherer, R. 2010. Teacher candidate responses to digital games: 21st-century skills development. Journal of Research on Technology in Education, 42(4), 409-425. 
Saunders, M., Lewis, P. and Thornhill, A., 2009. Research Methods for Business Students. (5th Edition) Pearson Education Ltd.

Smith, H. J., Higgins, S., Wall, K. and Miller, J., 2005. Interactive whiteboards: boon or bandwagon? A critical review of the literature. Journal of Computer Assisted Learning, 21(2), 91-101.

Tondeur, J., van Braak, J., Sang, G., Voogt, J., Fisser, P. and Ottenbreit-Leftwich, A., 2012. Preparing pre-service teachers to integrate technology in education: A synthesis of qualitative evidence. Computers \& Education, 59(1), 134-144.

Virvou, M., Katsionis, G. and Manos, K., 2005. Combining Software Games with Education: Evaluation of its Educational Effectiveness. Educational Technology \& Society, 8(2), 54-65.

Warren, S. J., Dondlinger, M. J., and Barab, S. A. 2008. A MUVE towards PBL writing: Effects of a digital learning environment designed to improve elementary student writing. Journal of Research on Technology in Education, 41(1), 113-140.

Wastiau, P., Blamire, R., Kearney, C., Quittre, V., Van de Gaer, E. and Monseur, C., 2013. The Use of ICT in Education: a survey of schools in Europe. European Journal of Education, 48: 11-27. doi: 10.1111/ejed.12020

Yee, N., 2006. Motivations for play in online games. CyberPsychology and behavior, $9(6), 772-775$. 